Nowoczesne Systemy Zarządzania

Zeszyt 15 (2020), nr 1 (styczeń-marzec)

ISSN 1896-9380, s. 71-85

DOI: $10.37055 / \mathrm{nsz} / 132721$

Modern Management Systems

Volume 15 (2020), No. 1 (January-March)

ISSN 1896-9380, pp. 71-85

DOI: $10.37055 / \mathrm{nsz} / 132721$
Instytut Organizacji i Zarządzania Wydział Bezpieczeństwa, Logistyki i Zarządzania

Wojskowa Akademia Techniczna

w Warszawie

Institute of Organization and Management Faculty of Security, Logistics and Management Military University of Technology

Metodyka wielokryterialnej analizy zmian stóp bezrobocia wybranych gospodarek światowych oraz prognozowanie modelem ARIMA stopy bezrobocia USA na przyszłość

\title{
Methodology of Multi-criteria Analysis of Changes in Unemployment Rates in Selected World Economies and Forecasting with the ARIMA Model of the US Unemployment Rate for the Future
}

\author{
Bartosz Kozicki \\ Wojskowa Akademia Techniczna, Wydział Bezpieczeństwa, Logistyki i Zarządzania, \\ bartosz.kozicki@wat.edu.pl, ORCID: 0000-0001-6089-952X \\ Jan Žukovskis \\ Vytautas Magnus University Agriculture Academy, Kowno, Litwa, \\ jan.zukovskis@vdu.It, ORCID: 0000-0002-8124-9195 \\ Grzegorz Mizura \\ Ministerstwo Obrony Narodowej \\ grzesiek_mizura@op.pl
}

\begin{abstract}
Abstrakt. W artykule przedstawiono metodykę wielokryterialnej analizy stóp procentowych bezrobocia w wybranych gospodarkach światowych oraz próby przeprowadzenia prognozowania stopy bezrobocia w USA na trzy przyszłe okresy. Badania rozpoczęto od analizy wielowymiarowej zmienności stóp procentowych bezrobocia w wybranych gospodarkach światowych w ujęciu sześciomiesięcznym w latach 2011-2018. Następnie przeprowadzono jej ocenę. Dalszym etapem badania była analiza i ocena szeregu czasowego danych dotyczących stóp procentowych bezrobocia w USA w ujęciu dynamicznym. Następnie zbudowano model prognostyczny ARIMA i wykonano prognozowanie na trzy przyszłe okresy.

Słowa kluczowe: bezrobocie, prognozowanie, model ARIMA.
\end{abstract}


Abstract. The article presents the methodology of multi-criteria analysis of unemployment interest rates in selected world economies, and an attempt to forecast the unemployment rate in the USA for three future periods. The research began with an analysis of the multidimensional volatility of unemployment interest rates in selected world economies on a six-month basis in 2011-2018. It was then assessed. The next stage of the study was the analysis and evaluation of the time series of data on the US unemployment interest rates in dynamic terms. Then, the ARIMA forecast model was built and forecasting for three future periods was performed.

Keywords: unemployment, forecasting, ARIMA model.

\section{Wstęp}

Tematyka bezrobocia podjęta $\mathrm{w}$ artykule jest istotna, ponieważ bezrobocie jest aspektem, który ma duży wpływ na trudnoodnawialny zasób ludzki, a tym samym może zwiększyć społeczne nakłady finansowe związane z zatrudnieniem.

Stopa bezrobocia stanowi odsetek siły roboczej, która nie ma pracy, lecz jest zarejestrowana jako poszukująca pracy. Bezrobocie na świecie w poszczególnych państwach oscyluje na różnych poziomach. Ma na to wpływ wiele czynników. Przykładowo z analizy literatury przedmiotu wynika, że powodem bezrobocia w Kanadzie są wysokie podatki, zbyt rozbudowana biurokracja, ograniczony wolny handel między prowincjami, który może być drogi i ograniczać powstawanie miejsc pracy (https://www.quora.com/What-are-the-three-main-causes-of-unemploymentin-Canada). Podkreślić należy, że Kanada zamknięta jest na inwestycje z innych krajów (np. firmy technologiczne) oraz kwestie imigracyjne. Z kolei analizując stopy bezrobocia w USA, można stwierdzić, że istnieją tam solidne fundamenty kształtujące rynek pracy i stopa bezrobocia $\mathrm{w}$ ujęciu dynamicznym powinna się obniżać (http://fortune.com/2018/05/04/unemployment-rate-century-low-percent/).

Zdaniem P. Dittmanna (2016, s. 13) prognozowanie jest racjonalnym, naukowym przewidywaniem przyszłych zdarzeń. Natomiast celem prognozowania jest zmniejszenie ryzyka związanego z popełnieniem błędu. Ma to duże znaczenie podczas przewidywania przyszłego poziomu stanu bezrobocia w wielu krajach. W literaturze przedmiotu istnieje szereg różnych klasyfikacji metod prognozowania, lecz jedną z najczęściej stosowanych jest podział metod na ilościowe i jakościowe. Z punktu widzenia niniejszego opracowania będą stosowane metody ilościowe.

Celem artykułu jest zaprezentowanie metodyki wielokryterialnej analizy stóp bezrobocia w wybranych gospodarkach światowych oraz próba wykonania prognozowania stopy bezrobocia w USA na trzy przyszłe okresy.

$\mathrm{W}$ artykule zastosowano metody badawcze w postaci analizy literatury, która dotyczy zagadnień związanych z bezrobociem i prognozowaniem, analizy dokumentów źródłowych, metody symulacji komputerowej oraz porównania. Narzędziem wykorzystanym w analizie danych było oprogramowanie Statistica. Zastosowano także następujące techniki wykres normalności, autokorelację, autokorelację cząstkową, regresję wieloraką oraz histogram. Artykuł składa się ze wstępu, czterech części merytorycznych, a także podsumowania i wniosków. 


\section{Analiza zmian stopy bezrobocia w wybranych gospodarkach światowych}

Pierwszym etapem analizy było zestawienie (rysunek 1) danych dotyczących stóp bezrobocia w USA, Kanadzie, Japonii, Australii i Polsce w latach 2011-2018 w ujęciu półrocznym.

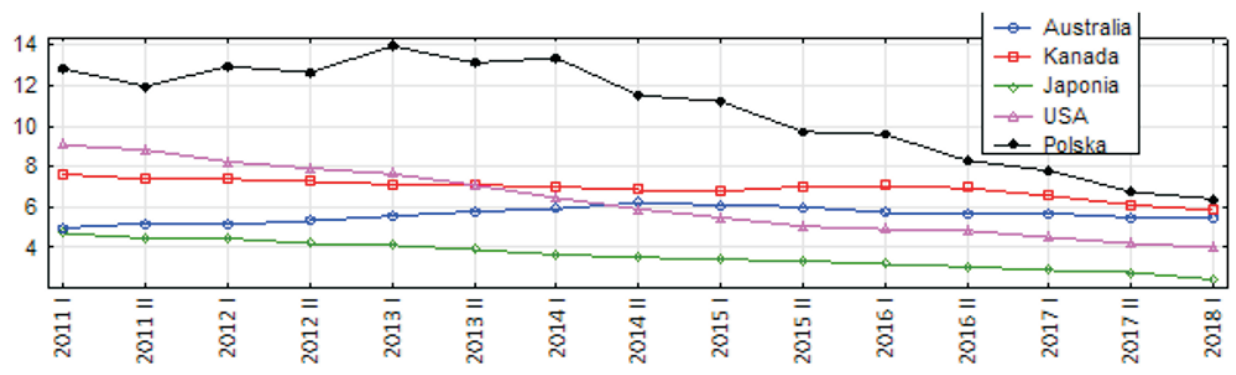

Rys. 1. Wykres liniowy bezrobocia w wybranych gospodarkach światowych w ujęciu półrocznym w latach 2011-2018

Źródło: Opracowanie własne na podstawie http://stat.gov.pl/obszary-tematyczne/rynek-pracy/ bezrobocie-rejestrowane/bezrobotni-zarejestrowani-i-stopa-bezrobocia-wyrownane-sezonowo-wlatach-2011-2018,5,1.html

Analiza danych zaprezentowanych na rysunku 1 pozwala zauważyć, że największy spadek stóp bezrobocia w rozpatrywanych gospodarkach zanotowano w Polsce. Co więcej, najniższy poziom bezrobocia zaobserwowano w Japonii. Spadki bezrobocia obserwuje się (oprócz Polski) w USA i Japonii. Natomiast w Australii i Kanadzie dla analizowanego okresu można przyjąć, że stopa bezrobocia była na stałym poziomie - lecz podkreślić należy, że w Australii z delikatną tendencją malejącą, a w Kanadzie - rosnącą.

Następnym etapem analizy było zastosowanie wykresu ramka-wąsy dla szeregów czasowych zawierających dane stóp procentowych bezrobocia $\mathrm{w}$ analizowanych gospodarkach światowych (rysunek 2).

Analiza danych zawartych na rysunku 2 pozwala na stwierdzenie, że największy rozstęp międzykwartylowy był w Polsce. Na drugim miejscu uplasowały się Stany Zjednoczone. Najmniejsze rozstępy międzykwartylowe przypadają na Australię i Kanadę. W analizowanych gospodarkach nie obserwuje się wartości odstających i ekstremalnych.

Następnie zbadano normalność rozkładów szeregów czasowych danych dotyczących stóp bezrobocia $\mathrm{w}$ analizowanych gospodarkach $\mathrm{w}$ ujęciu dynamicznym (rysunek 3). 


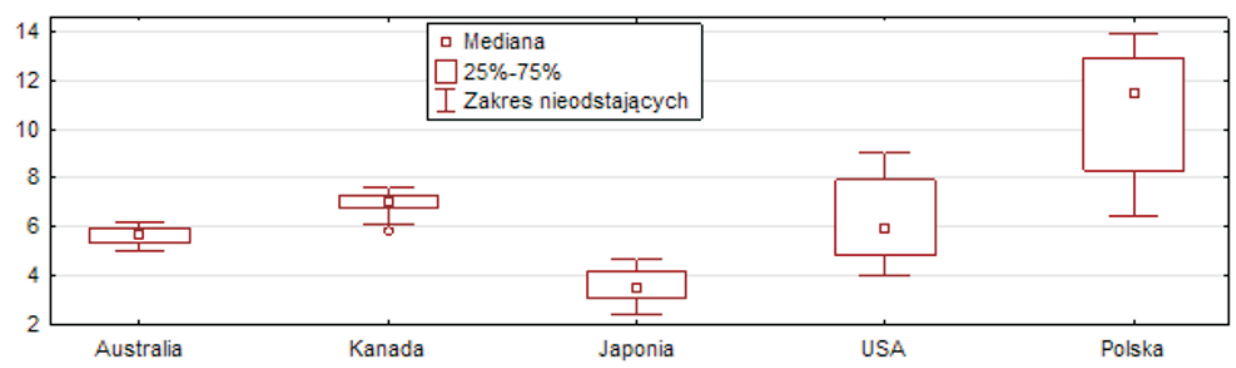

Rys. 2. Wykres ramka-wąsy w wybranych gospodarkach światowych w ujęciu półrocznym w latach 2011-2018

Źródło: Opracowanie własne na podstawie http://stat.gov.pl/obszary-tematyczne/rynek-pracy/ bezrobocie-rejestrowane/bezrobotni-zarejestrowani-i-stopa-bezrobocia-wyrownane-sezonowo-wlatach-2011-2018,5,1.html

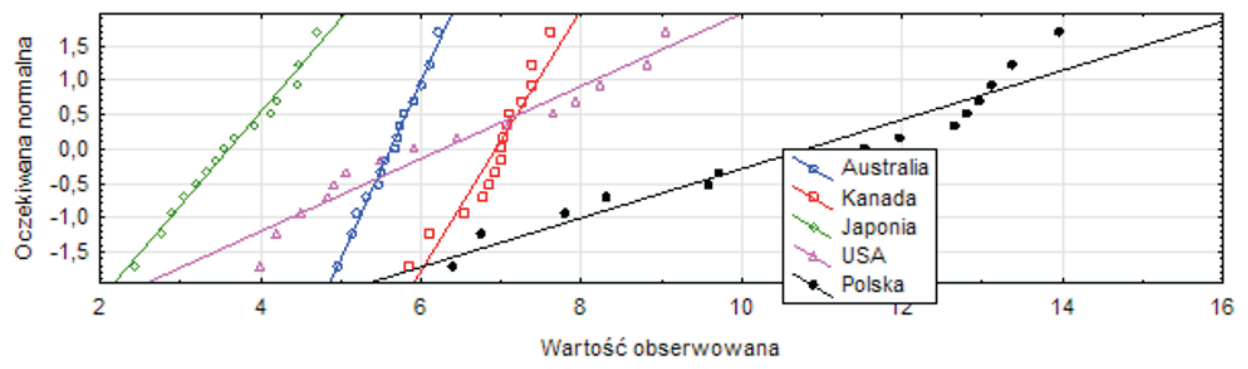

Rys. 3. Wykres normalności w wybranych gospodarkach światowych w ujęciu półrocznym w latach 2011-2018

Źródło: Opracowanie własne

Oceną rysunkow 3 i 4 jest stwierdzenie, że rozkłady reszt w rozpatrywanych gospodarkach są zbliżone do normalnych. Dodatkowo Australia, Kanada, USA i Japonia mają rozkłady prawostronnie skośne, natomiast Polska skośny lewostronnie.

Następnie dla celów badawczych przeprowadzono analizę wielowymiarową danych dotyczących stóp bezrobocia w analizowanych gospodarkach światowych z wykorzystaniem Twarzy Chernoffa (rysunek 5).

Przeprowadzona analiza wielowymiarowa $\mathrm{z}$ wykorzystaniem Twarzy Chernoffa (rysunek 5) wskazuje na dużą zmienność stóp bezrobocia - szczególnie w Polsce, na poziomie około $8 \%$ w latach 2011-2018. Podobnie, lecz na niższym poziomie, spadki są widoczne w USA i wynoszą około 5\%. Japonia również wykazuje spadek na poziomie około $2 \% \mathrm{w}$ rozpatrywanym okresie. W Australii obserwuje się niewielką tendencję wzrostową stopy bezrobocia o około 0,5\%, a w Kanadzie spadek stopy bezrobocia o około $2 \%$. 

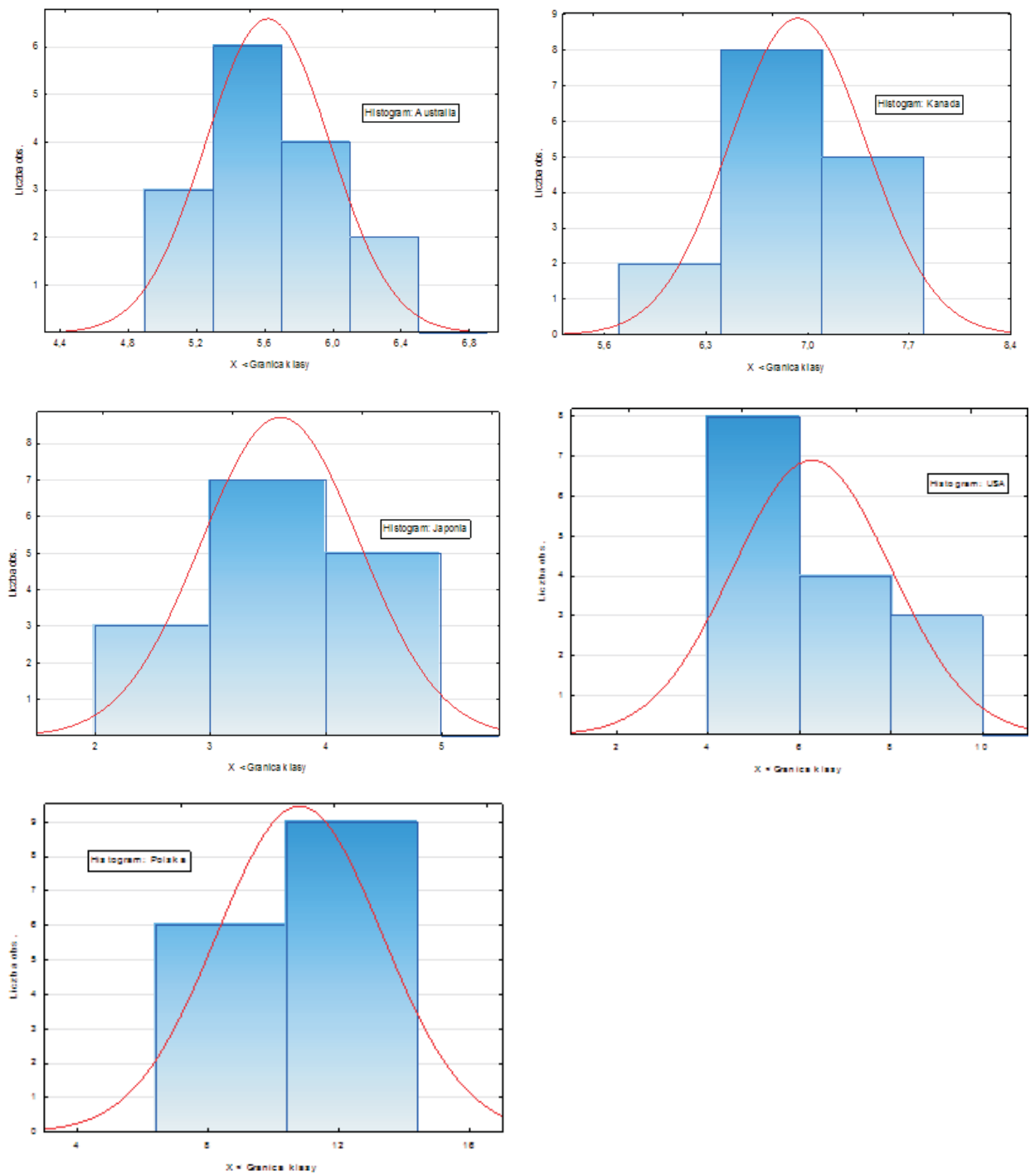

Rys. 4. Zastosowanie histogramu w wybranych gospodarkach światowych w ujęciu półrocznym w latach 2011-2018 Źródło: Opracowanie własne 

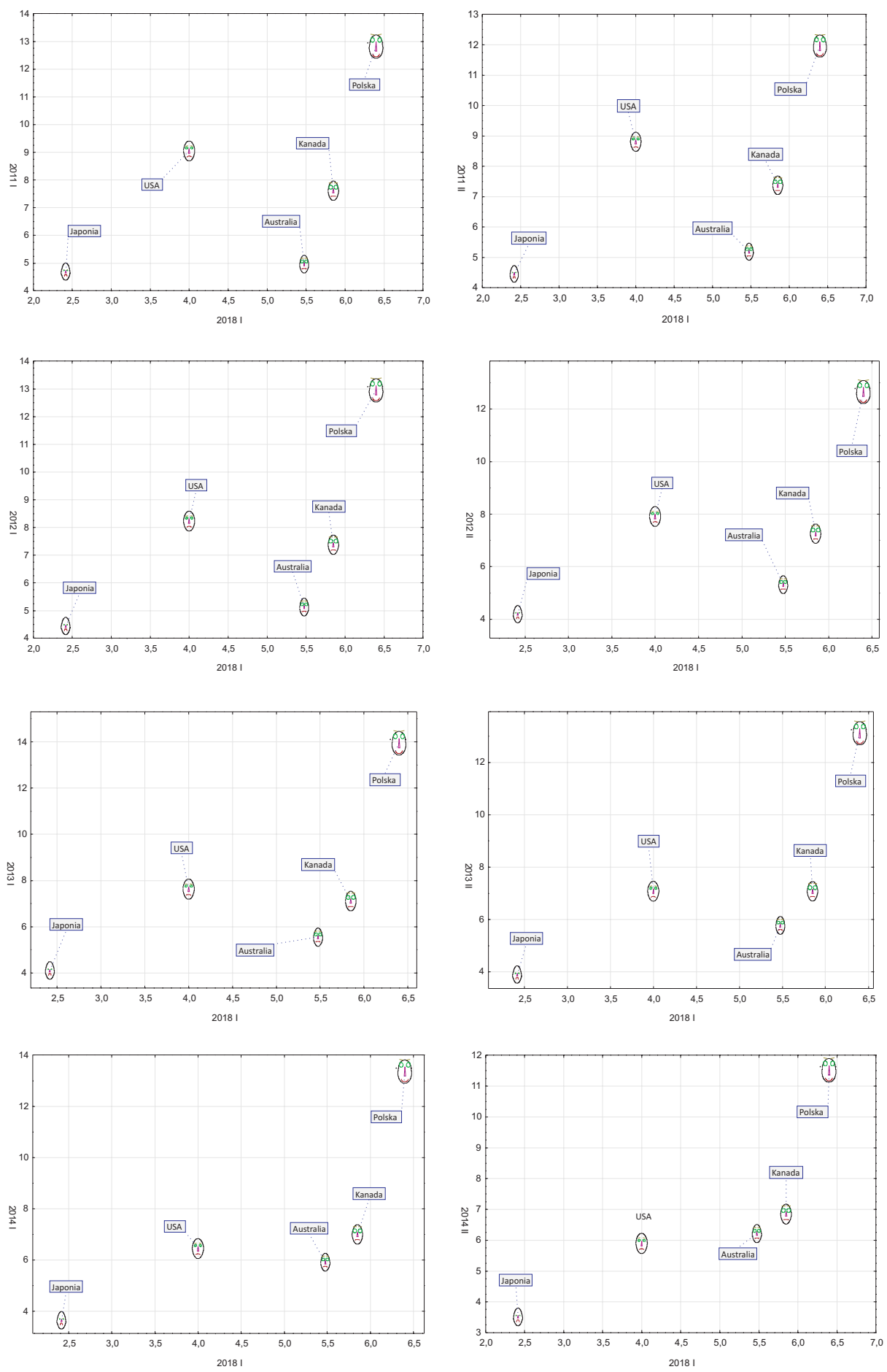

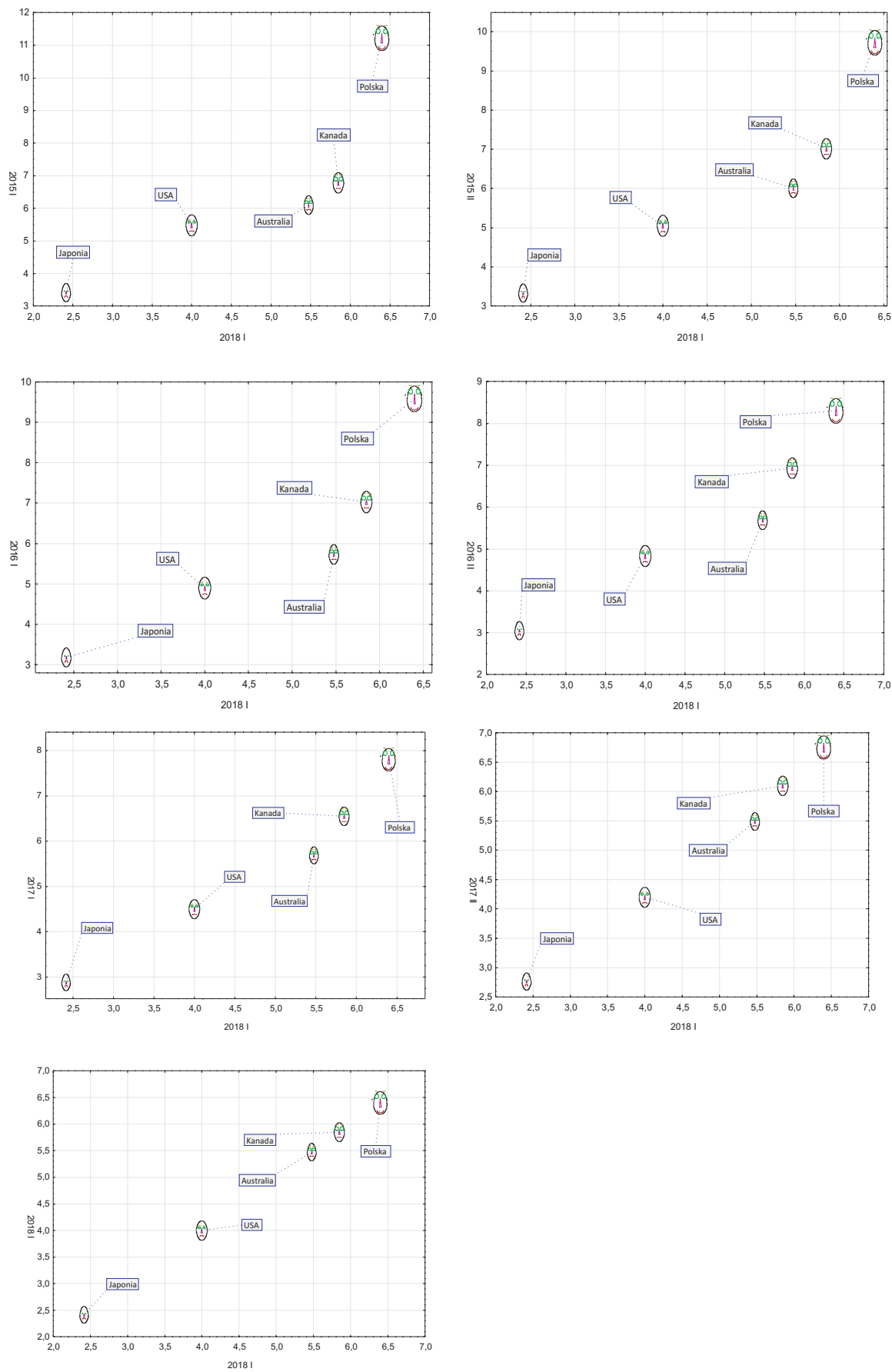

Rys. 5. Analiza wielokryterialna z zastosowaniem Twarzy Chernoffa w wybranych gospodarkach światowych w ujęciu półrocznym w latach 2011-2018 
Najbardziej odróżniającą się twarzą od pozostałych jest twarz Polski. Wynika to z różnicy poziomu stopy bezrobocia i zmienności w stosunku do pozostałych analizowanych państw. Podobna zmienność stopy bezrobocia, lecz o niższym poziomie, została zaobserwowana w USA i Japonii, co jest uwidocznione najbardziej podobnymi rysami twarzy na rysunku 5. Podobne rysy twarzy dotyczą Australii i Kanady i świadczą o zmiennie stałym poziomie stopy bezrobocia w ujęciu dynamicznym, z niewielkimi odchyleniami od średniej arytmetycznej.

Dalszym etapem badań będzie przeprowadzenie prognozowania szeregu czasowego danych dotyczących stopy bezrobocia w USA w latach 2011-2018 w ujęciu półrocznym na rok 2019. Prognozowanie zostanie poprzedzone wykonaniem analizy i oceny szeregu czasowego $\mathrm{z}$ wykorzystaniem zaawansowanych narzędzi badawczych.

\section{Analiza danych dotyczących stopy bezrobocia w USA}

Na rysunku 6 zestawione są dane dotyczące stopy bezrobocia w USA w ujęciu półrocznym w latach 2011-2018. Na podstawie analizy danych zaobserwowano zjawisko trendu. Stało się to przesłanką do nakreślenia kolorem czerwonym linii trendu, którą opisano funkcją $\mathrm{Y}=9,3352-0,3832 \cdot \mathrm{x}$.

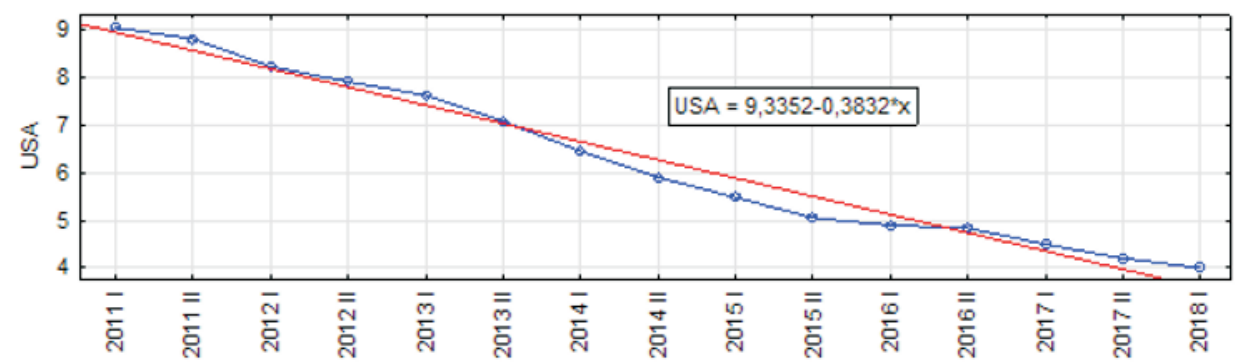

Rys. 6. Wykres liniowy danych dotyczących bezrobocia w USA w ujęciu półrocznym w latach 2011-2018 (dane pierwotne)

Źródło: Opracowanie własne

Dalszym etapem analizy było zbadanie istnienia zależności w analizowanym szeregu czasowym pierwotnym. W tym celu użyto narzędzi badawczych w postaci autokorelacji i autokorelacji cząstkowej (rysunek 7).

Analiza rysunku 7 pozwala zauważyć, że szereg czasowy pierwotny jest niestacjonarny. W obserwowanym szeregu czasowym widoczny jest silny trend o charakterze malejącym. W celach badawczych podjęto próbę sprowadzenia analizowanego 
szeregu czasowego pierwotnego do stacjonarności przez zastosowanie różnicowania stopnia pierwszego. Wyniki przekształceń szeregu czasowego pierwotnego zestawiono na rysunku 8.

Analiza danych zawartych na rysunku 8 pozwala stwierdzić, że szereg czasowy pierwotny po przekształceniach jest stacjonarny. W celach badawczych wykorzystano narzędzia badawcze w postaci autokorelacji i autokorelacji cząstkowej do potwierdzenia stacjonarności analizowanego szeregu czasowego (rysunek 9).
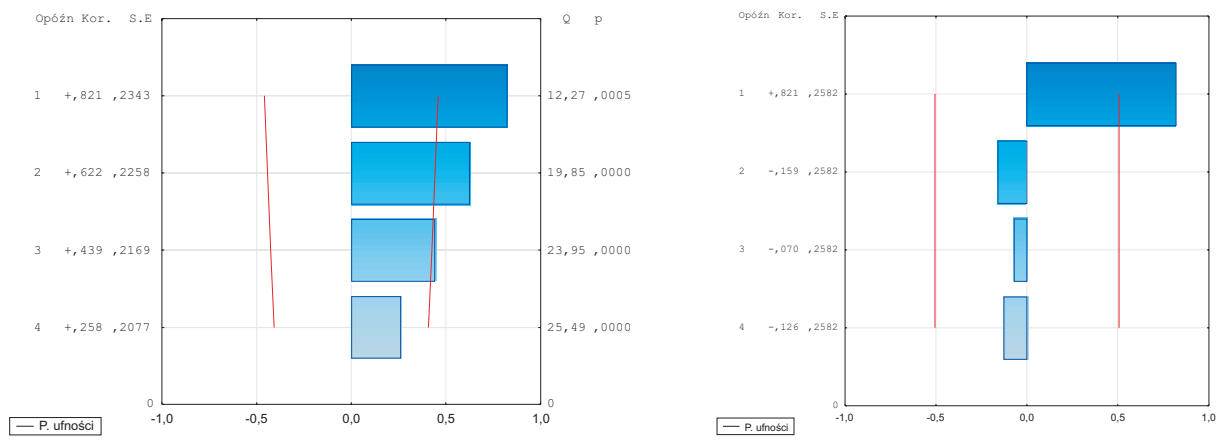

Rys. 7. Zastosowanie autokorelacji i autokorelacji cząstkowej do danych dotyczących bezrobocia w USA w ujęciu półrocznym w latach 2011-2018

Źródło: Opracowanie własne

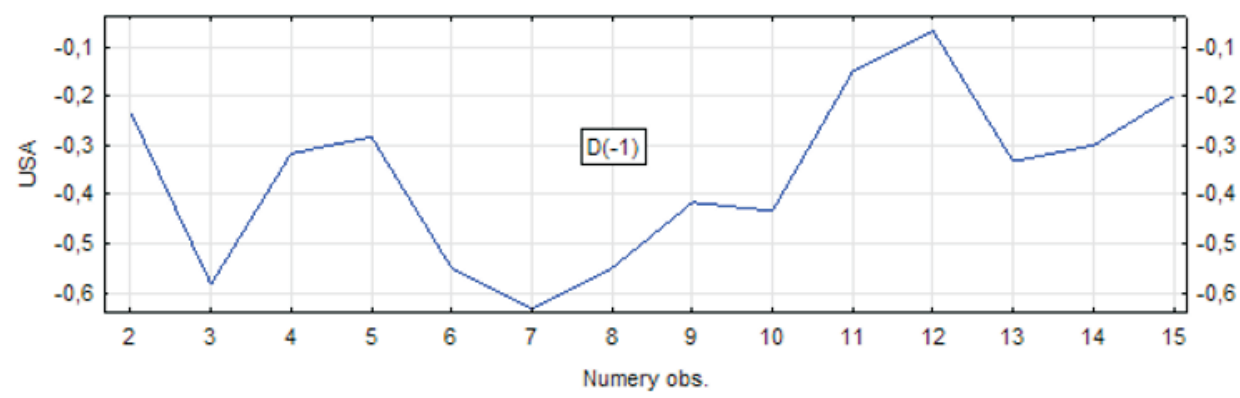

Rys. 8. Różnicowanie stopnia pierwszego danych dotyczących bezrobocia w USA w ujęciu półrocznym w latach 2011-2018

Źródło: Opracowanie własne 

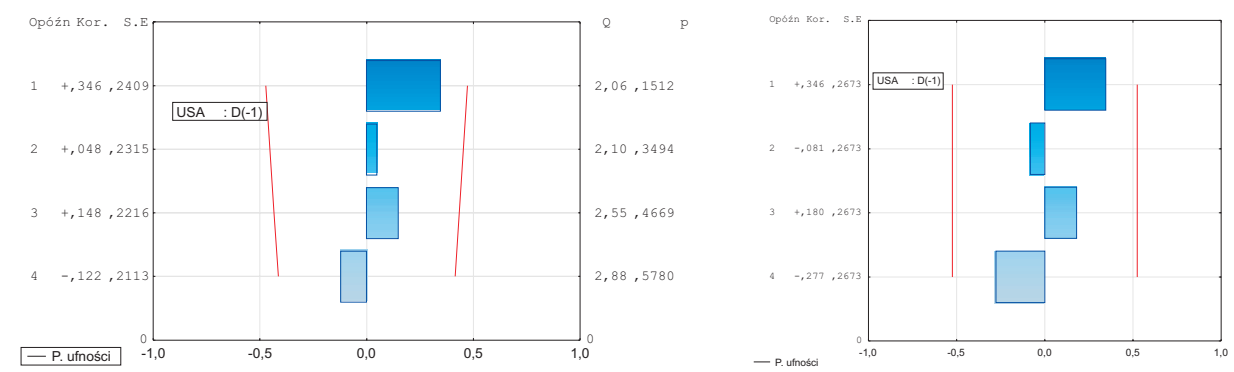

Rys. 9. Zastosowanie autokorelacji i autokorelacji cząstkowej do szeregu czasowego pierwotnego po różnicowaniu Źródło: Opracowanie własne

Zastosowanie autokorelacji i autokorelacji cząstkowej (rysunek 9) jednoznacznie potwierdza stacjonarność analizowanego szeregu czasowego pierwotnego po różnicowaniu stopnia pierwszego i wskazuje na zjawisko „białego szumu”.

Następnie zbudowano model regresji wielorakiej do potwierdzenia istnienia trendu w analizowanym szeregu czasowym pierwotnym. W tym celu użyto trzech predyktorów w postaci zmiennych: $\mathrm{t}, \mathrm{t}^{2} \mathrm{i}$ lnt. Istotność predyktorów w zbudowanym modelu regresji wielorakiej zestawiono w tabeli 1.

Tabela 1. Zero-jedynkowy model regresji wielorakiej

\begin{tabular}{|c|c|c|c|c|c|c|}
\hline \multirow{2}{*}{$\mathrm{N}=15$} & \multicolumn{5}{|c|}{$\mathrm{R}=0,99734097 \mathrm{R} \wedge 2=0,99468902$ Popraw. $\mathrm{R} 2=0,99324057$} \\
\cline { 2 - 7 } & $\mathrm{b}^{*}$ & Błąd std. & $\mathrm{b}$ & Błąd std. & $\mathrm{t}(11)$ & $\mathrm{p}$ \\
\hline W. wolny & & & 9,957506 & 0,130496 & 76,30494 & 0,000000 \\
\hline $\mathrm{t}$ & $-2,49994$ & 0,342560 & $-0,969242$ & 0,132813 & $-7,29781$ & 0,000015 \\
\hline $\mathrm{t}^{2}$ & 1,10717 & 0,217257 & 0,026088 & 0,005119 & 5,09611 & 0,000346 \\
\hline $\ln \mathrm{t}$ & 0,46308 & 0,147933 & 1,026801 & 0,328013 & 3,13036 & 0,009571 \\
\hline
\end{tabular}

Źródło: Opracowanie własne

Zbudowany model regresji wielorakiej ma postać $Y=9,957506-0,969242 \bullet t+$ $+0,026088 \bullet t^{2}+1,026801 \bullet \operatorname{lnt}$. Następnie przeprowadzono analizę reszt zbudowanego modelu regresji wielorakiej (rys. 10).

$\mathrm{Z}$ oceny przeprowadzonej analizy reszt zbudowanego modelu regresji wielorakiej (rys. 10) wynika, że ma miejsce dobre dopasowanie wartości przewidywanych i obserwowanych. W resztach zbudowanego modelu istnieją zależności. Rozkład reszt jest lewostronnie skośny, zbliżony do normalnego. 


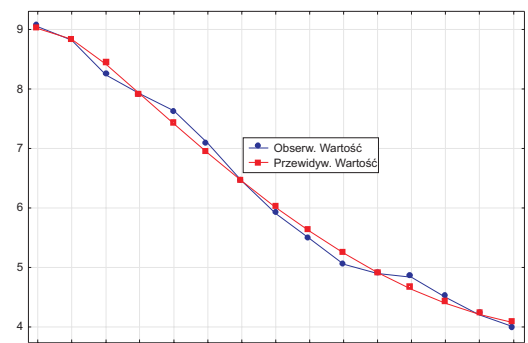

苦

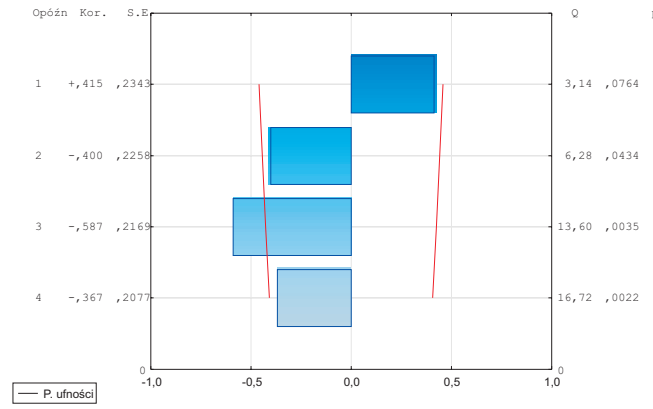

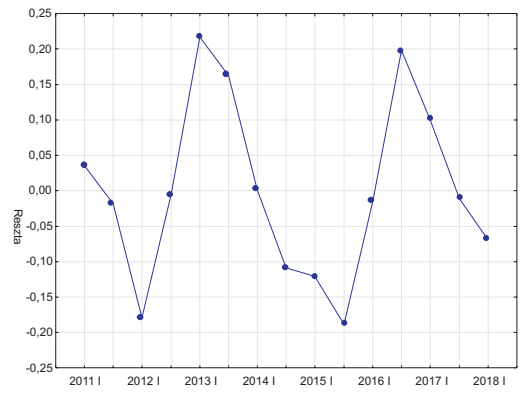

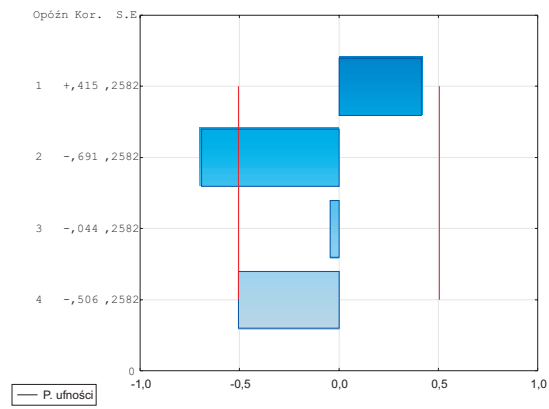

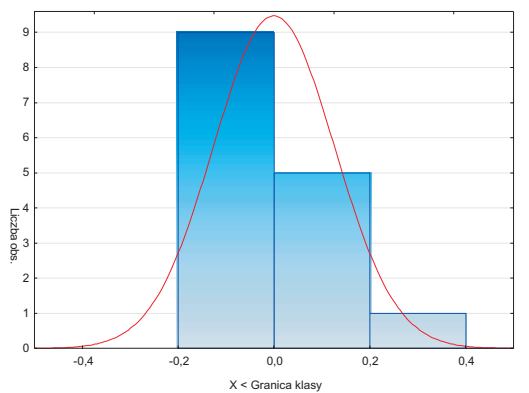

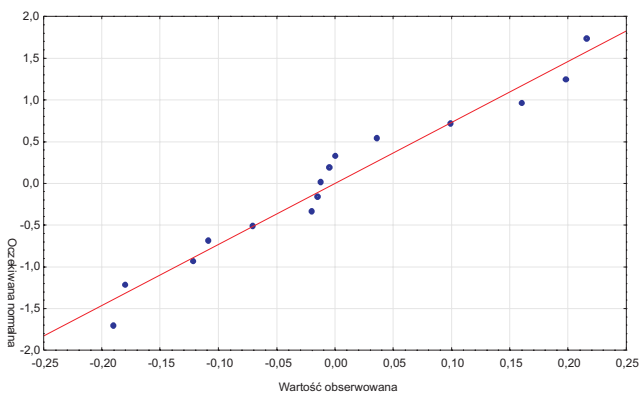

Rys. 10. Analiza reszt zbudowanego modelu regresji wielorakiej

Źródło: Opracowanie własne

\section{Ocena danych dotyczących stopy bezrobocia w USA}

Oceną przeprowadzonej analizy jest wykrycie zależności w analizowanym szeregu czasowym w postaci trendu. Ważną oceną jest również sposób sprowadzenia szeregu do postaci stacjonarnej. Zaobserwowana prawidłowość będzie miała zastosowanie przy budowie modelu prognozowania. Powyższa ocena stała się przesłanką do wyboru modelu prognostycznego do wykonania prognozy na przyszłość - zastosowany tu zostanie model klasy ARIMA. 


\section{Prognozowanie stopy bezrobocia w USA}

W celu przeprowadzenia prognozowania szeregu czasowego pierwotnego zbudowano model ARIMA $(1,1,0)$. Istotność użytych predyktorów w modelu ARIMA $(1,1,0)$ przedstawiono w tabeli 2 .

Tabela 2. Budowa modelu ARIMA $(1,1,0)$ dla szeregu pierwotnego

\begin{tabular}{|c|c|c|c|c|c|c|}
\hline \multirow{3}{*}{ Parametr } & \multicolumn{7}{|c|}{ Przekształcenia: D(1) } \\
\cline { 2 - 7 } & Parametr & Asympt. & Asympt. & $\mathrm{p}$ & Dolna gr. & Górna gr. \\
\hline $\mathrm{p}(1)$ & 0,889060 & 0,137840 & 6,449925 & 0,000022 & 0,591274 & 1,186845 \\
\hline
\end{tabular}

Źródło: Opracowanie własne

Następnie przeprowadzono analizę i ocenę reszt prognozy zbudowanego modelu ARIMA $(1,1,0)$ (rysunek 11).
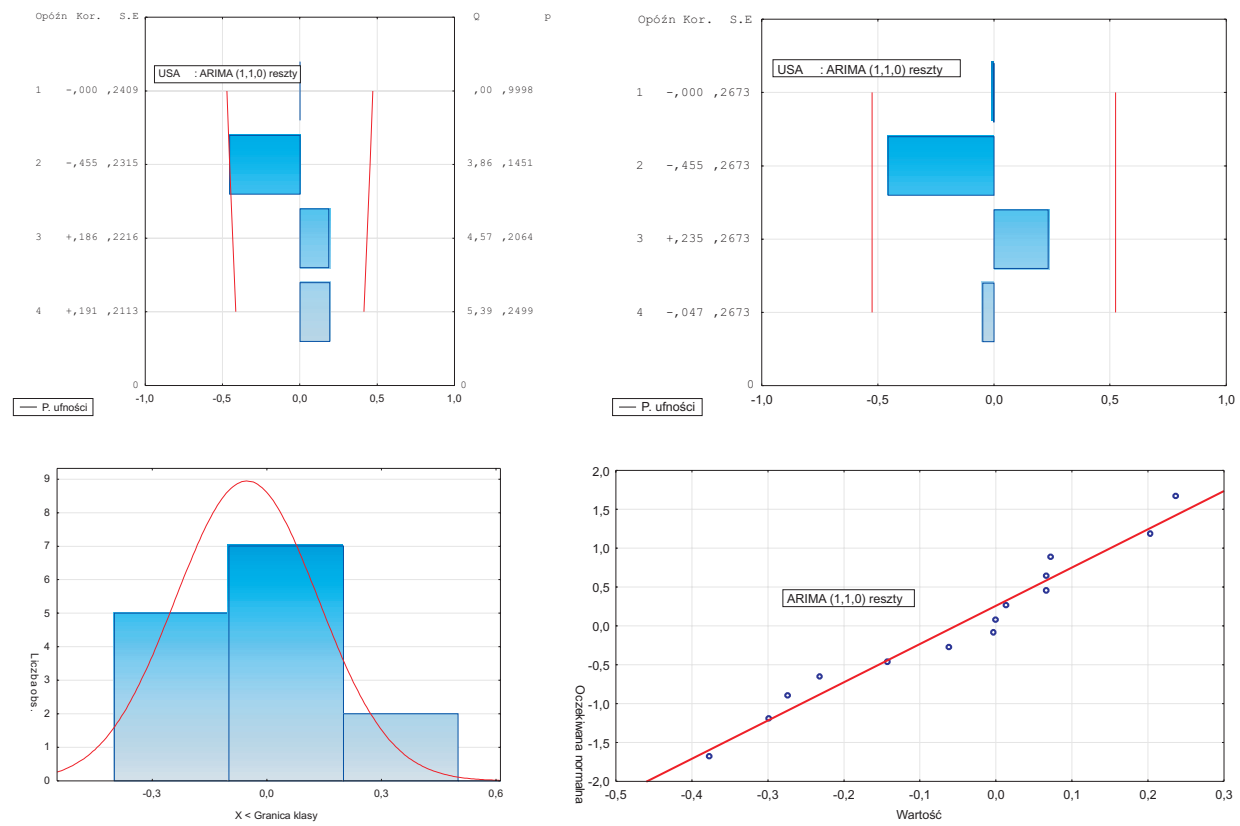

Rys. 11. Analiza reszt prognozy zbudowanego modelu ARIMA $(1,1,0)$ dla szeregu pierwotnego Źródło: Opracowanie własne 
Analiza reszt prognozy zbudowanego modelu ARIMA $(1,1,0)$ pozwala na stwierdzenie, że model jest poprawny. Reszty wykazują zjawisko „białego szumu”, natomiast ich rozkład jest normalny. Następnie wykonano prognozowanie zbudowanym modelem ARIMA $(1,1,0)$ na trzy przyszłe okresy - rok 2019 (rysunek 12).

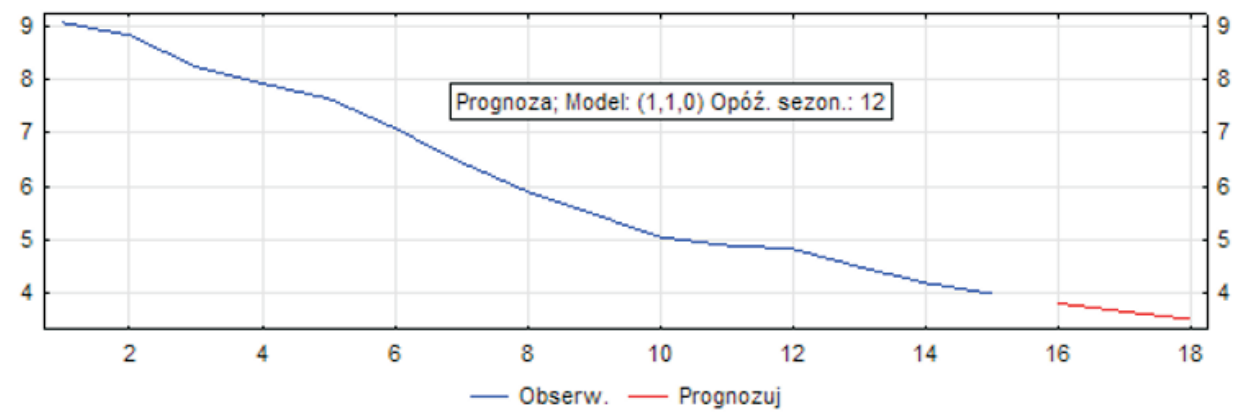

Rys. 12. Prognoza szeregu czasowego pierwotnego na trzy przyszłe okresy wykonana modelem ARIMA $(1,1,0)$

Źródło: Opracowanie własne

Na podstawie powyższych wyników można stwierdzić, że bezrobocie w USA w 2019 roku będzie wykazywało trend o charakterze malejącym (rysunek 12).

\section{Podsumowanie i wnioski}

W opracowaniu przedstawiono metodykę wielokryterialnej analizy stóp bezrobocia w wybranych gospodarkach światowych, oraz prognozowanie stopy bezrobocia w USA na przyszłość.

Przeprowadzona analiza i ocena stopy bezrobocia w wybranych gospodarkach wskazała m.in. bardzo dużą zmienność stopy bezrobocia w Polsce. W latach 20112018 stopa procentowa spadała z około 14\% do 7\%. Najprawdopodobniej spadek stopy bezrobocia wynikał ze wzrostu gospodarczego. W USA i Japonii również były widoczne spadki stopy bezrobocia w ujęciu dynamicznym, lecz na niższym poziomie niż w Polsce. Australia i Kanada w ujęciu dynamicznym cechują się stałym poziomem stopy bezrobocia.

W ramach badania przeprowadzono analizę i ocenę zmiany stóp procentowych wybranych gospodarek światowych oraz wykonano prognozowanie szeregu czasowego pierwotnego stopy bezrobocia w USA na trzy przyszłe okresy. Prognozowanie zostało poprzedzone wykonaniem analizy i oceny danych retrospektywnych dotyczących stopy bezrobocia w USA w latach 2011-2018 w ujęciu półrocznym. 
Następnie na podstawie uzyskanej oceny zbudowano model ARIMA $(1,1,0)$, którym wykonano prognozowanie na 2019 rok. Prognozowanie zostało poprzedzone analizą i oceną reszt prognozy modelu ARIMA $(1,1,0)$. Wyniki prognozy na trzy przyszłe okresy zestawiono w tabeli 3 .

Tabela 3. Wyniki prognozy modelem ARIMA $(1,1,0)$ danych dotyczących stopy bezrobocia w USA w ujęciu półrocznym w latach 2011-2018 na 2019 rok

\begin{tabular}{|c|c|c|}
\hline Lp. & Miesiąc & $\begin{array}{l}\text { Wyniki prognozy stopy bezrobocia w USA modelem } \\
\text { ARIMA }(1,1,0) \text { na trzy przyszłe okresy - } 2019 \text { rok }\end{array}$ \\
\hline 1 & 2018 (lipiec-grudzień) & 3,82 \\
\hline 2 & 2019 (styczeń-czerwiec) & 3,66 \\
\hline 3 & 2019 (lipiec-grudzień) & 3,52 \\
\hline
\end{tabular}

Źródło: Opracowanie własne

Zastosowanie skonstruowanego modelu ARIMA przy utrzymanym trendzie malejącym stopy bezrobocia w USA może usprawnić prognozowanie w instytucjach zajmujących się analizą, oceną i prognozą danych retrospektywnych dotyczących gospodarki narodowej.

\section{BIBLIOGRAFIA}

[1] Begg D., Vernasca G., Fischer S., Dornbusch R., 2014, Makroekonomia, Polskie Wydawnictwo Ekonomiczne, Warszawa.

[2] Dittmann P., 2008, 2016, Prognozowanie w przedsiębiorstwie. Metody i ich zastosowanie, Wolters Kluwer Polska Sp. z o.o., Kraków.

[3] Dittmann P. i In., 2009, 2016, Prognozowanie w zarządzaniu przedsiębiorstwem, Wydawnictwo Nieoczywiste, Imprint GAB Media.

[4] Dittmann P. I IN., 2011, 2016, Prognozowanie w zarządzaniu sprzedażą i finansami przedsiębiorstwa, Wydawnictwo Nieoczywiste, imprint GAB Media.

[5] Gabrusewicz W., Kamela-Sowińska A., Poetschke H., 2000, Rachunkowość zarzadcza, Polskie Wydawnictwo Ekonomiczne, Warszawa.

[6] Kozicki B., Waściński T., Brzeziński M., Tomaszewski J., 2018, Zastosowanie prognozy do planowania przychodów przedsiębiorstwa, GMiL 1231-2037, Nr 5, s. 332-334.

[7] Kozicki B., Waściński T., Brzeziński M., Lisowska A., 2018, Cost forecast in a shipping company, Transport means, Litwa.

[8] Kozicкi B., 2018, Metodyka prognozowania zysku, „Systemy Logistyczne Wojsk”, SLW nr 2(49).

[9] Kozicki B., WAściŃsKi T., LisowsKa A., 2018, Selection of optimal forecasting method for a CPI inflation measure in Poland, Wyd. Katedra Zarządzania Jakością i Wiedzą UMCS Lublin.

[10] Makridakis S.G., Wheelwright S.C., Hyndman R.J., 1998, Forecasting methods and applications, John Wiley and Sons, New York.

[11] PAPIEŻ M., ŚMIECH S., 2015, Modelowanie i prognozowanie cen surowców energetycznych, Wydawnictwo C.H.Beck, Warszawa. 
[12] Rabiej M., 2018, Analizy statystyczne z programami Statistica i Exel, Helion, Gliwice.

[13] Ręкlewski M., Ryczkowski M., 2016, The Polish regional labour market indicator and its links to other well-being measures, „Comaparative Economic Research”, nr 19(3), DOI: 10.1515/cer2016-0023.

[14] SuchwaŁko A., Zagdański A., 2016, Analiza i prognozowanie szeregów czasowych. Praktyczne wprowadzenie na podstawie środowiska $R$, PWN, Warszawa.

[15] ItsCanadaTime, https://www.quora.com/What-are-the-three-main-causes-of-unemploymentin-Canada.

[16] Bloomberg http://fortune.com/2018/05/04/unemployment-rate-century-low-percent/. 